\title{
Pengembangan E-Magazine Berbasis Multipel Representasi untuk Pembelajaran Kimia di SMA pada Materi Larutan Elektrolit dan Non Elektrolit
}

\author{
Endang Jariati ${ }^{1}$, Elvi Yenti ${ }^{2}$ \\ ${ }^{1,2}$ Program Studi Pendidikan Kimia, Universitas Islam Negeri Sultan Syarif Kasim Riau \\ e-mail: \\ 1 endangjariati@gmail.com \\ 2 elviyenti@uin-suska.ac.id
}

\begin{abstract}
ABSTRACK.
This research aims to develop learning media in the form of E-Magazine based on multiple representations for chemistry learning in high school on electrolyte and non-electrolyte solution material. E-Magazine is designed using Adobe Flas CSG software. The type of research used is research and development or research and development (R\&D) with the Borg and Gall research model with stages including research and data collection, planning, product development, small-scale trials and product revisions. Data collection techniques used in the form of observation, interviews and questionnaires. Based on the results of the validation of material experts, it was found that the validity of the E-Magazine based on multiple representations for chemistry learning in high school on the resulting electrolyte and non-electrolyte solution material was included in the very valid category with a validity value of $100 \%$ and for the validation of media experts a validity value of $88,46 \%$ with very valid category. The results of the practicality test obtained a practicality value of $95 \%$ in the very practical category and for student responses to the overall contents of the E-Magazine it was found that $50 \%$ of students said it was good and $50 \%$ of students said it was very good.
\end{abstract}

Keywords: e-magazine, multiple representation, electrolyte and non-electrolyte solution

\begin{abstract}
ABSTRAK.
Penelitian ini bertujuan untuk mengembangkan media pembelajaran berupa E-Magazine berbasis multipel representasi untuk pembelajaran kimia di SMA pada materi larutan elektrolit dan non elektrolit. E-Magazine didesain menggunakan Software Adobe Flas CS6. Jenis penelitian yang digunakan adalah penelitian dan pengembangan atau research and development (R\&D) dengan model penelitian Borg dan Gall dengan tahapan meliputi penelitian dan pengumpulan data, perencanaan, pengembangan produk, uji coba skala kecil dan revisi produk. Teknik pengumpulan data yang digunakan berupa observasi, wawancara dan angket. Berdasarkan hasil validasi ahli materi diperoleh bahwa validitas E-Magazine berbasis multipel representasi untuk pembelajaran kimia di SMA pada materi larutan elektrolit dan non elektrolit yang dihasilkan termasuk dalam kategori sangat valid dengan nilai validitas $100 \%$ dan untuk validasi dari ahli media diperoleh nilai validitas sebesar $88,46 \%$ dengan kategori sangat valid. Hasil uji kepraktisan diperoleh nilai praktikalitas sebesar 95\% dengan kategori sangat praktis dan untuk respon siswa terhadap keseluruhan isi E-Magazine diperoleh bahwa 50\% siswa menyatakan bagus dan 50\% siswa menyatakan sangat bagus.
\end{abstract}

Kata kunci: e-magazine, multipel representasi, larutan elektrolit dan non elektrolit 


\section{PENDAHULUAN}

Gabel dan Johnstone menyatakan bahwa lmu kimia merupakan bidang kajian yang kompleks karena didalamnya terdapat tiga level representasi yaitu level makroskopik, mikroskopik dan simbolik (Fitria, et al., 2016). Ketiga representasi tersebut sangat diperlukan dalam memahami konsep kimia yang abstrak secara mendalam. Oleh karena itu, kemampuan dalam memahami kimia berkaitan erat dengan kemampuan menjelaskan kimia menggunakan ketiga level representasi (Saselah \& Qadar, 2017).

Level makroskopik merupakan level konkret, karena pada level ini siswa dapat mengamati fenomena yang terjadi baik melalui percobaan yang dilakukan atau dalam kehidupan sehari-hari (Indrayani, 2014). Fenomena yang dapat diamati tersebut seperti perubahan warna, timbulnya nyala lampu, pembentukan gas, terbentuknya endapan dan lain sebagainya (Herda et al., 2014). Kemudian level mikroskopik ini memberikan penjelasan pada tingkat partikel seperti ion-ion molekul-molekul dan susunan atom-atom, sedangkan level simbolik digunakan untuk mempresentasikan fenomena makroskopik melalui persamaan kimia, mekanisme reaksi, grafik, persamaan matematika dan analogi-analogi (Indrayani, 2014).

Berdasarkan penelitian terdahulu diantara ketiga level representasi tersebut level yang masih sulit dipahami oleh siswa adalah level mikroskopik. Beberapa diantaranya seperti penelitian Devantak yang menunjukkan bahwa siswa memperoleh nilai yang rendah terhadap soal yang berkaitan dengan menggambar bentuk mikroskopik dari larutan ionik (Herda et al., 2014). Penelitian Yani et al., (2015) menunjukkan bahwa hanya $3 \%$ siswa yang memahami aspek mikroskopik dari larutan elektrolit dan non elektrolit. (Saselah \& Qadar, (2017) menyatakan bahwa banyak siswa memiliki kesulitan mendeskripsikan konsep-konsep abstrak yang terdapat dalam materi kimia $\mathrm{Hal}$ ini dikarenakan level mikroskopik ini merupakan fenomena yang nyata tetapi tidak dapat dilihat (Hsin-kai et al.,, 2000).

Bila siswa dapat memahami dan menghubungkan ketiga level representasi, maka pemahaman siswa terhadap konsep kimia lebih mendalam (Chandrasegaran et al., 2007). Sebagai contoh untuk menjelaskan mengapa lampu dapat menyala pada larutan natrium klorida diuji daya hantarnya (makroskopik), maka siswa perlu memahami pergerakan dan keadaan ion-ion, elektron, molekul air, molekul suatu zat didalam larutan maupun dikabel penghantar (mikroskopik) dan menuliskannya kedalam bentuk persamaan reaksi (simbolik), maka dengan demikian dapat dikatakan bahwa pengetahuan kimia, khususnya pada materi larutan elektrolit dan non elektrolit dibangun dengan ketiga level representasi (Sirhan, 2007).

Berdasarkan hasil observasi di SMA IT Al-Fityah Pekanbaru diperoleh bahwa masih banyak siswa yang mengalami kesulitan dalam memahami materi pada level mikroskopik salah satunya pada materi larutan elektrolit dan non elektrolit. Hal ini terlihat dari jawaban yang diberikan oleh siswa terhadap soal berkaitan dengan menggambarkan bentuk mikroskopik larutan, padatan dari garam dan gula. Selain itu hasil wawancara dengan guru mata pelajaran kimia didapatkan informasi bahwa guru menggunakan buku dan metode praktikum dan usaha lain yang digunakan guru untuk membantu pemahaman level mikroskopik terhadap siswa seperti menampilkan video animasi. Selain itu, selama proses pembelajaran juga tidak cukup hanya menyajikan seputar konsep materi larutan elektrolit dan non elektrolit tetapi dibutuhkan juga penyajian materi larutan elektrolit dan non elektrolit dalam kehidupan sehari-hari. Hal ini didasarkan pada silabus kurikulum 2013 revisi 2016 bahwa pada mata pelajaran kimia materi larutan elektrolit dan non elektrolit terdapat kegiatan pembelajarannya siswa diharapkan untuk dapat menyimpulkan fungsi dan cara mengatasi kekurangan elektrolit dalam tubuh manusia. 
Berdasarkan permasalahan tersebut solusi yang dapat dilakukan adalah dengan merujuk pada pendapat Gabel dan Krajik yang menyatakan untuk membantu siswa memahami ilmu kimia dengan ketiga level representasi secara bersamaan maka perlu adanya pendekatan baru yaitu menggunakan teknologi komputer (Saselah \& Qadar, 2017). Melalui pemanfaatan teknologi komputer dapat membuat suatu bahan ajar yang dapat disisipi gambar, animasi, teks audio dan video sebagai upaya alternatif menyajikan materi pembelajaran kimia.

Salah satu media yang cocok untuk dikembangkan dalam materi larutan elektolit dan non elektrolit adalah majalah. Majalah merupakan media yang berisi konten-konten dan gambar dikemas secara menarik dan ditampilkan dengan sederhana agar memudahkan dalam memahami konsep. Selain itu, majalah juga berisi informasi-informasi edukatif yang menambah wawasan (Nurjanah, 2014). Majalah yang akan dikembangkan ini berupa majalah elektronik atau E-Magazine yang pada dasarnya sama dengan majalah cetak. Perbedaanya E-Magazine tidak menggunakan bahan baku kertas melainkan file digital yang dapat diakses melalui media elektronik seperti komputer, laptop, handphone, android, iphone, ipad dan teknologi lainnya (Nurjanah, 2014).

Penelitian mengenai pengembangan majalah pada pembelajaran kimia telah banyak diteliti seperti penelitian Putri et al., (2019) yang menyatakan bahwa E-Magazine ini layak dan praktis sebagai bahan ajar dan sumber belajar pada materi kesetetimbangan kimia. (Pakpahan et al., 2016) juga menyatakan bahwa majalah kimia layak digunakan pada proses pembelajaran materi hukum-hukum dasar kimia. Berdasarkan uraian di atas maka tujuan dari penelitian ini adalah untuk menghasilkan suatu produk media pembelajaran berupa E-Magazine berbasis multipel representasi untuk pembelajaran kimia di Sekolah Menengah Atas dengan bantuan software adobe flash CS6 pada materi larutan elektrolit dan non elektrolit dan juga untuk mengetahui tingkat validitas, praktikalitas dan respon siswa terhadap media tersebut.

\section{METODOLOGI}

Penelitian ini dimulai dari akhir bulan Januari sampai awal Oktober 2019 yang bertempat di Universitas Islam Negeri Sultan Syarif Kasim Riau dan SMA IT Al-Fityah Pekanbaru. Subjek dalam penelitian ini adalah pihak yang melakukan penilaian terhadap produk yang dihasilkan seperti ahli media pembelajaran, ahli materi pembelajaran, satu orang guru mata pelajaran kimia serta sepuluh orang siswa kelas XI SMA IT Al- Fityah Pekanbaru, sedangkan objeknya yaitu sesuatu yang akan dinilai yaitu media pembelajaran E-Magazine berbasis multipel representasi untuk pembelajaran kimia pada materi larutan elektrolit dan non elektrolit. Jenis Penelitian ini adalah penelitian research and development $(R \& D)$ dengan model penelitian Borg and Gall. Model penelitian ini mempunyai sepuluh langkah penelitian. Namun, pada penelitian ini hanya melakukan lima langkah yaitu penelitian dan pengumpulan data, perencanaan, pengembangan produk tahap awal, uji coba skala kecil dan revisi produk (Emzir, 2017).

Penelitian ini diawali dengan langkah penelitian dan pengumpulan data yang dilakukan dengan cara studi lapangan dan studi pustaka. Studi lapangan yaitu observasi tempat dan kondisi sekolah seperti melihat sarana dan prasarana sekolah, sumber belajar yang digunakan. Kemudian wawancara kepada guru mata pelajaran dan siswa, serta penyebaran angket tentang penggunaan komputer atau laptop sehari-hari oleh siswa. Langkah selanjutnya adalah perencanaan seperti menyesuaikan kompetensi inti (KI), kompetensi dasar (KD), serta menyesuaikan kegiatan pembelajaran dengan silabus kurikulum 2013. Selain itu pada langkah ini juga terdapat pemilihan media yang akan didesain, merancang desain awal media dalam bentuk prototype dan storyboard serta penyusunan instrumen yang kemudian langsung divalidasi oleh validator instrumen.

Langkah selanjutnya adalah pengembangan produk tahap awal berupa pengembangan media E-Magazine berbasis multipel representasi yang disesuaikan dengan rancangan dalam prototype dan storyboard. Kemudian divalidasi oleh validator ahli media dengan kualifikasi 
pendidikan minimal strata dua (S2) yang memiliki pengalaman serta keahlian dalam perancangan atau pengembangan media dan validator ahli materi dengan kualifikasi pendidikan sama minimal strat dua (S2) bidang kimia serta memiliki pengalaman dalam mengajar kimia. Jika hasilnya belum valid maka akan dilakukan revisi dan akan divalidasi kembali oleh kedua validator tersebut. Setelah dinyatakan valid maka langkah selanjutnya adalah uji coba terbatas.

Uji coba terbatas ini dilakukan di satu sekolah dengan 1 orang guru kimia (subjek) untuk uji coba praktikalitas dan 10 orang siswa (subjek) untuk melihat tanggapan atau respon dalam menggunakan E-Magazine dengan memberikan angket. Langkah terakhir yaitu melakukan revisi produk yang dilihat dari hasil angket berupa komentar, saran untuk perbaikan selanjutnya. Tahapan yang dilakukan dapat dilihat pada gambar berikut

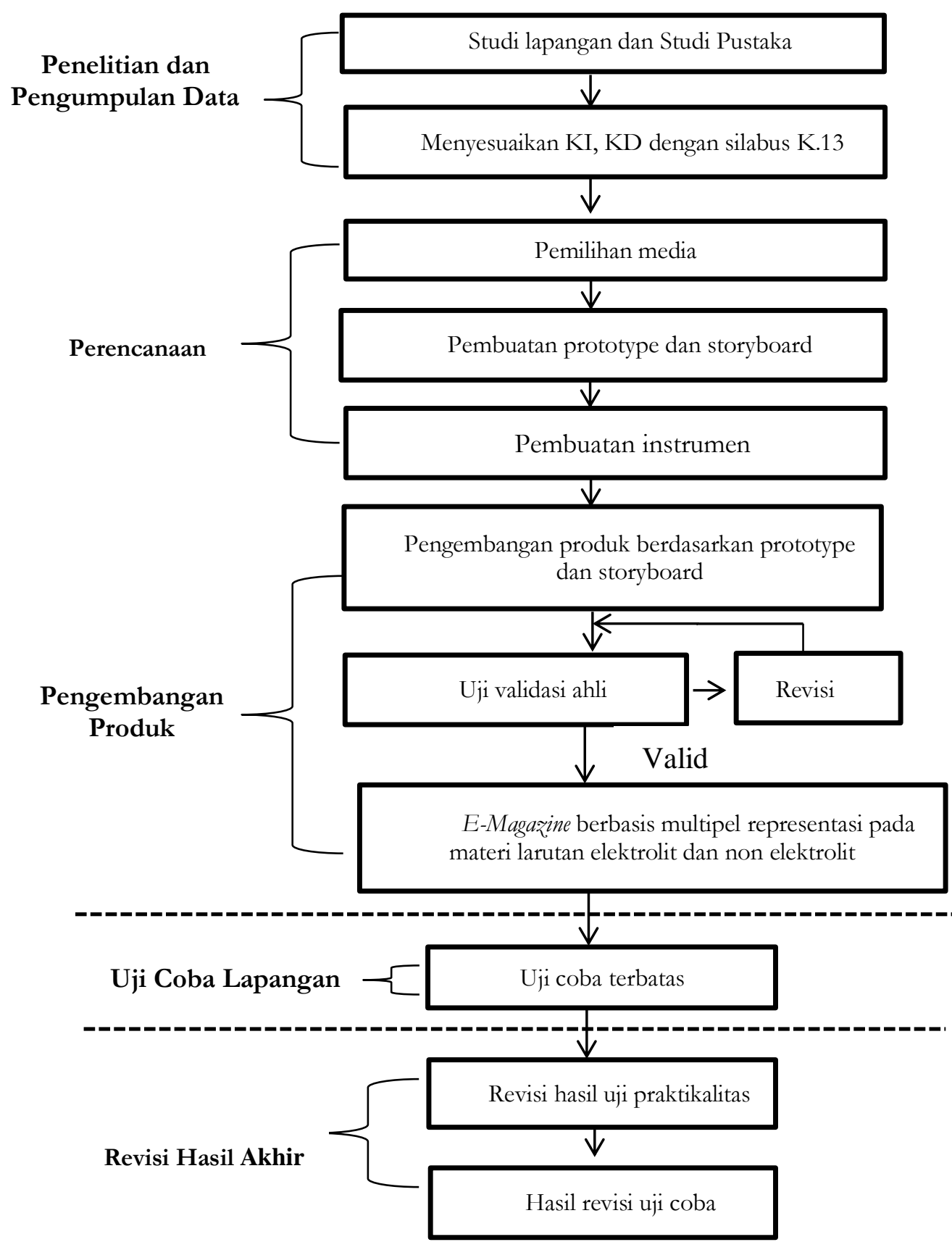

Gambar 1. Bagan prosedur penelitian 
Dalam penelitian ini teknik pengumpulan data yang dilakukan berupa observasi, wawancara dan angket. Jenis angket yang digunakan ada dua yaitu angket tertutup dan angket semi terbuka. Angket tertutup terdiri dari angket untuk ahli media pembelajaran, ahli materi pembelajaran dan uji praktikalitas oleh guru mata pelajaran kimia dengan menggunakan skala likert 4 poin yaitu sangat baik(SB), baik (B), kurang baik (KB) dan sangat kurang baik (SKB).

Alasan menggunakan skala likert 4 poin tersebut adalah agar memperoleh pandangan responden secara lebih jelas mengenai penyataan-pernyatan yang disajikan dalam angket dengan alasan adanya pemberian kata tengah akan memberikan arti ganda, tersedianya kategori jawaban tengah menimbulkan kecenderungan jawaban tengah bagi responden yang memiliki keraguan dalam menanggapi pernyataan, dan jika disediakan kategori jawaban tengah akan menghilangkan banyak informasi dari responden (Dwitariani \& Suputra, 2016).

Aspek penilaian dan skala angket tertutup diadaptasi dan modifikasi dari Kurniawati, (2019). Adapun angket semi terbuka digunakan untuk angket respon siswa. Pada angket ini, responden diberi sejumlah pilihan alternatif yang tersedia tetapi masih diberi ruang untuk mengisi jawaban lain apabila alternatif jawaban yang tersedia dianggap tidak sesuai dengan pilihannya (Sopingi, 2015). Aspek penilaian angket semi terbuka ini diadaptasi dan modifikasi dari (Anggraeni \& Kustijono, 2013). Aspek yang dinilai oleh validator ahli materi terdiri dari tiga aspek yaitu kelayakan isi, kelayakan penyajian dan kelayakan bahasa. Validator ahli media menilai dua aspek yaitu kegrafikan dan rekayasa perangkat lunak. Praktikalitas media dinilai oleh guru mata pelajaran kimia yang aspek penilaiannya tersiri dari kelayakan isi, kelayakan penyajian, kelayakan bahasa, kemenarikan dan rekayasa perangkat lunak. Sedangkan respon siswa terdiri dari lima aspek penilaian yaitu format media, kualitas media, kejelasan media, dan ketertarikan siswa.

Teknik analisis data pada penelitian ini adalah teknik analisis data kualitatif dan kuantitatif. Data kualitatif didapatkan dari saran, masukan atau kritikan responden, sedangkan data kuantitatif didapatkan dari nilai yang diberikan didalam angket. Perhitungan untuk menentukan persentase kevalidan dan kepraktisan media dengan rumus sebagai berikut:

$$
\begin{aligned}
& \text { Persentase kevalidan }=\frac{\text { skor yang diperoleh }}{\text { skor maksimal }} \times 100 \% \\
& \text { Persentase kepraktisan }=\frac{\text { skor yang diperoleh }}{\text { skor maksimal }} \times 100 \%
\end{aligned}
$$

Hasil persentase tersebut kemudian ditafsirkan dalam bentuk pengertian kualitatif sebagai berikut (Riduwan, 2007):

Tabel 1. Interpretasi nilai validitas dan praktikalitas

\begin{tabular}{ccc}
\hline No & Interval & Kriteria \\
\hline 1 & $81 \%-100 \%$ & Sangat valid/ Sangat praktis \\
\hline 2 & $61 \%-80 \%$ & Valid / praktis \\
\hline 3 & $41 \%-60 \%$ & Cukup valid / cukup praktis \\
\hline 4 & $21 \%-40 \%$ & Kurang valid / kurang praktis \\
\hline 5 & $0 \%-20 \%$ & Tidak valid / tidak praktis \\
\hline
\end{tabular}

\section{TEMUAN DAN PEMBAHASAN}

Penelitian ini merupakan penelitian research and development (R\&D) yang menghasilkan produk berupa E-Magazine berbasis multipel representasi untuk pembelajaran kimia di SMA pada materi larutan elektrolit dan non elektrolit yang layak digunakan sebagai media pembelajaran sehingga dapat membantu siswa memahami materi pembelajaran kimia dengan tiga level representasi. 
Langkah pertama yang dilakukan yaitu penelitian dan pengumpulan data meliputi studi lapangan dan studi pustaka. Studi lapangan dilakukan dengan cara observasi dan wawancara. Berdasarkan hasil observasi diketahui bahwa sekolah tidak memiliki labor komputer dan labor kimia. Tetapi, ada izin yang diberikan sekolah kepada siswa untuk membawa laptop jika diperlukan dan dibutuhkan dalam proses pembelajaran di kelas. Dengan demikian, sekolah tersebut memiliki potensi jika dikembangkan media pembelajaran yang menggunakan komputer atau laptop.

Berdasarkan hasil wawancara dengan guru dan siswa diperoleh informasi bahwasannya dalam proses pembelajaran materi larutan elektrolit dan non elektrolit guru menggunakan buku cetak, praktikum dan sesekali menampilkan video animasi. Kemudian Analisis dilakukan terhadap buku yang digunakan tersebut menunjukkan bahwa buku hanya didominasi dengan tulisan dan gambar- gambar mikroskopik berwarna hitam dan putih yang masih kurang menarik. Selanjutnya hasil wawancara dengan siswa menunjukkan bahwa kebanyakan siswa mengalami kesulitan pada materi kimia. Hal ini didukung dari jawaban yang diberikan siswa terhadap pertanyaan penggambaran mikroskopik larutan, padatan dari garam dan gula. Hasilnya menujukkan bahwa jawaban siswa kurang tepat. Pada umumnya siswa menggambarkan molekul larutan garam hanya ada molekul $\mathrm{Na}$ dan $\mathrm{Cl}$, sedangkan pada padatan garam terdapat molekul $\mathrm{NaCl}$ yang berjauhan. Kemudian pada larutan dan padatan gula banyak siswa yang tidak memberikan jawaban.

Melihat hasil-hasil dari observasi lapangan tersebut maka dilakukan juga studi pustaka dengan cara mengumpulkan informasi dari buku dan jurnal. Hasil dari studi pustaka diperoleh bahwa pembelajaran yang menggunakan buku dan praktikum belum bisa memberikan pemahaman terhadap level mikroskopik. Hal ini didasari oleh beberapa penelitian seperti penelitian Herda et al., (2014) yang menyatakan bahwa penyajian level mikroskopik pada buku hanya berupa gambar statis dan penelitian Simehatte et al., (2016) yang menyatakan bahwa pembelajaran dengan metode praktikum hanya dapat mengamati konsep-konsep makroskopik seperti lampu menyala terang, redup atau tidak menyala, timbul gelembung gas yang banyak atau sedikit. Untuk mengatasi masalah tersebut Gabel dan Krajik menyatakan bahwa pemahaman siswa terhadap ketiga level representasi dapat dibantu dengan menggunakan komputer (Saselah \& Qadar, 2017). Informasi lain dari studi pustaka ini juga dilakukan terhadap level mikroskopik yaitu bentuk-bentuk molekul yang akan disajikan dalam media (Kotz et al., 2012)

Pada langkah kedua, dilakukan tahap perencanaan seperti penyesuaian kompetensi inti, kompetensi dasar dan kegiatan pembelajaran dengan silabus kurikulum 2013, pemilihan media, merancang desain awal dan menyusun instrumen. Berdasarkan tahap penyebaran angket penggunaan komputer dan silabus kurikulum 2013 yang menunjukkan bahwa siswa dituntut untuk mengetahui larutan elektrolit dan non elektrolit dalam kehidupan sehar-hari maka media yang dikembangkan adalah majalah berbasis elektronik atau yang dikenal dengan E-Magazine. Pada tahap pemilihan media ini juga dilakukan pemilihan aplikasi yang akan digunakan yaitu adobe flash CS6. Aplikasi ini memiliki banyak fungsi seperti pembuatan animasi objek, animasi iklan, dan pendukung animasi halaman web. Berkas yang dihasilkan berupa file dengan format swf, .exe., adobe AIR, HTML 5, AIR For Android dan AIR For IOS (Wibanto, 2017). Perancangan desain awal dalam penelitian ini diawali dengan membuat prototype yang berisi konten-konten yang akan disajikan dalam media dan dilanjutkan dengan membuat storyboard. Menyusun instrument angket untuk ahli materi pembelajaran, ahli media pembelajaran, praktikalitas guru dam respon siswa.

Pada langkah ketiga, pengembangan produk dilakukan sesuai dengan prototype, storyboard dan penilaian instrumen. Produk yang dihasilkan berupa file dengan format .exe. yang bertujuan agar E-Magazine dapat dibuka disegala jenis leptop atau komputer tanpa harus menginstall software adobe flash CS6. Adapun pengembangan E-Magazine ini terdiri atas halaman depan, redaktur, kata pengantar dan daftar isi, bekal awal materi, cerita bergambar biografi ahli kimia, info kesehatan, sumber listrik, islamikpedia, kimia kreatifitas, teka-teki kimia, daftar rujukan dan profil. 
Jika media telah selesai maka akan divalidasi oleh ahli materi dan ahli media pembelajaran. Proses validasi ini dilakukan beberapa kali untuk mendapatkan hasil yang maksimal. Berdasarkan penilaian dari validator ahli materi, diperoleh saran dan masukan yaitu perbaiki rumus molekul gula, ganti tanda $\rightarrow$ dengan kata menjadi pada representasi simbolik, video diganti dengan video berbahasa indonesia, perbaiki kata elektrolat menjadi elektrolit, perbaiki gambar bentuk molekul larutan $\mathrm{HCl}$ dan $\mathrm{CH}_{3} \mathrm{COOH}$, perbaiki lampu pada animasi larutan $\mathrm{CH}_{3} \mathrm{COOH}$. Setelah semua saran diperbaiki lalu peneliti melakukan validasi kembali ke ahli materi dengan hasil data secara kuantitatif disajikan pada tabel 2

Tabel 2. Hasil akhir uji validitas ahli materi pembelajaran terhadap E-Magazine berbasis multipel representasi pada materi larutan elektrolit dan non elektrolit

\begin{tabular}{ccccc}
\hline No & Aspek penilaian & Skor & Persentase & Kriteria \\
\hline 1 & Kelayakan isi & 32 & $100 \%$ & Sangat valid \\
\hline 2 & Kelayakan penyajian & 8 & $100 \%$ & Sangat valid \\
\hline 3 & Kelayakan bahasa & 16 & $100 \%$ & Sangat valid \\
\hline & Junlah & $\mathbf{5 6}$ & $\mathbf{1 0 0 \%}$ & Sangat valid \\
\hline
\end{tabular}

Berdasarkan tabel di atas, hasil kuantitatif dari validator materi pada aspek kelayakan isi, kelayakan penyajian dan kelayakan bahasa masing-masing memperoleh skor sebesar $100 \%$ dengan kategori sangat valid sehingga Nilai rata-rata validitas dari ahli materi terhadap E-Magazine adalah 100\% dengan kategori sangat valid.

Hasil validasi selanjutnya diperoleh dari validator ahli media. Saran dan masukan dari validator ahli media yaitu rapikan tulisan pada cover, pada menu help ganti satu kata dari poinnya dengan kata menghidupkan, perjelas warna tulisan pada sumber, perjelas gambar dan tulisan pada cerita bergambar, perbesar gambar dan bentuk molekul dan tambahkan keterangan, pindahkan menu profil dan help pada lembaran E-Magazine agar tidak terputus-putus saat dibuka, tambahkan kata islamicpedia pada halaman islamicpedia, tambahkan keterangan bentuk molekul dan representasi simbolik pada animasi larutan, serta perjelas gambar pada info kesehatan. Hasil validasi dari ahli pembelajaran terhadap E-Magazine secara kuantitatif dapat dilihat pada tabel 3 berikut

Tabel 3. Hasil akhir uji validitas ahli media pembelajaran terhadap $E$-Magazine berbasis multipel representasi pada materi larutan elektrolit dan non elektrolit

\begin{tabular}{clccl}
\hline No & Aspek penilaian & Skor & Persentase & \multicolumn{1}{c}{ Kriteria } \\
\hline 1 & Kegrafikan & 38 & $86.36 \%$ & Sangat valid \\
\hline 2 & Rekayasa perangkat lunak & 8 & $100 \%$ & Sangat valid \\
\hline & Jumlah & $\mathbf{4 6}$ & $\mathbf{8 8 . 4 6 \%}$ & Sangat valid \\
\hline
\end{tabular}

Berdasarkan tabel 3 di atas terlihat bahwa pada aspek kegrafikan diperoleh nilai 86,36\% dengan kategori sangat valid dan pada aspek rekayasa perangkat lunak diperoleh nilai 100\% dengan kategori sangat valid. Nilai rata-rata validitas dari ahli media pembelajaran untuk E-Magazine adalah sebesar $88,46 \%$ dengan kategori sangat valid. Suatu buku non teks salah satunya adalah majalah dikatakan valid jika persentase penilaiannya adalah tinggi (Yuliyanto \& Rohaeti, 2013).

Pada langkah keempat, dilakukan uji coba terbatas yang dilakukan dengan guru dan siswa. Uji praktikalitas yang dinilai oleh guru dilakukan dengan menunjukkan dan menjelaskan tentang penggunaan E-Magazine berbasis multipel representasi untuk pembelajaran kimia di SMA pada materi elektrolit dan non elektrolit lalu meminta tanggapan guru dan siswa. 
Tabel 4. Hasil akhir uji praktikalitas guru mata pelajaran kimia terhadap E-Magazine berbasis multipel representasi pada materi larutan elektrolit dan non elektrolit

\begin{tabular}{clccl}
\hline No & Aspek penilaian & Skor & Persentase & Kriteria \\
\hline 1 & Kelayakan isi & 32 & $100 \%$ & Sangat praktis \\
\hline 2 & Kelayakan penyajian & 8 & $100 \%$ & Sangat praktis \\
\hline 3 & Kelayakan bahasa & 7 & $87.5 \%$ & Sangat praktis \\
\hline 4 & Kemenarikan & 22 & $91.66 \%$ & Sangat praktis \\
\hline 5 & Rekayasa perangkat lunak & 7 & $87.5 \%$ & Sangat praktis \\
\hline & Jumlah & $\mathbf{7 6}$ & $\mathbf{9 5 \%}$ & Sangat praktis \\
\hline
\end{tabular}

Berdasarkan hasil akhir dari penilaian guru hasil yang didapatkan dari 5 aspek meliputi aspek kelayakan isi, penyajian, bahasa, kemenarikan dan perangkat lunak dengan 20 butir soal diperoleh jumlah skor 76 dengan persentase kevalidan 95\% termasuk dalam kategori sangat valid. Langkah selanjutnya yang dilakukan adalah dengan melakukan uji coba kepada 10 orang siswa SMA IT Al-Fityah pekanbaru dengan menggunakan angket semi terbuka.

Pada aspek format media, $70 \%$ siswa menyatakan bahwa pengoprasian media sangat mudah. Pada Aspek kualitas media, $100 \%$ siswa menyatakan bahwa mereka menyukai bagian animasi atau video dan 50\% siswa menyatakan tidak menyukai background E-Magazine. Pada aspek kejelasan media, $60 \%$ siswa menyatakan bahwa tidak ada bagian yang sulit dipahami dalam media dan $60 \%$ siswa menyatakan perlu ada perbaikan varian warna E-Magazine. Kemudian pada aspek ketertarikan media, diperoleh bahwa 100\% siswa menyatakan E-Magazine dan 60\% siswa menyatakan E-Magazine mendukung pemahaman pada materi larutan elektrolit dan non elektrolit, serta 50\% siswa menyatakan E-Magazine sangat bagus dan 50\% lagi menyatakan bagus. Berdasarkan uraian tersebut maka dapat dinyatakan bahwa keseluruhan respon siswa terhadap EMagazine adalah baik. Selain itu, saran perbaikan dari respon siswa adalah perlu adanya perbaikan terhadap background dan varian warna E-Magazine.

Pada langkah kelima, dilakukan revisi produk. Revisi produk merupakan tahap akhir yang dilakukan dalam penelitian ini. Pada tahap ini E-Magazine akan direvisi sesuai hasil uji praktikalitas dan respon siswa untuk menghasilkan produk akhir E-Magazine berbasis multipel representasi untuk pembelajaran kimia di SMA pada materi larutan elektrolit dan non elektrolit yang layak. Adapun hasil akhir dari E-Magazine yang dikembangkan adalah sebagai berikut:

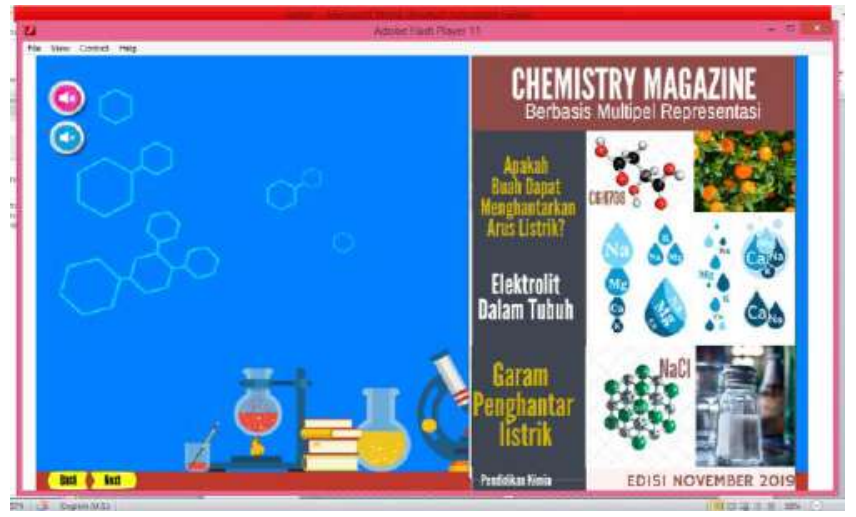

Gambar 2. Halaman awal

Pada halaman awal ini terdapat cover E-Magazine. Tampilan pada cover ini terdapat gambar (makroskopik), bentuk molekul (mikroskopik), dan rumus molekul (simbolik). Selain itu terdapat tombol back and next yang berfungsi untuk membuka halaman selanjutnya dan halaman sebelumnya. Kemudian terdapat 2 tombol bagian kiri atas yang berfungsi untuk menghidupkan backsound dan tombol mematikan backsound. 


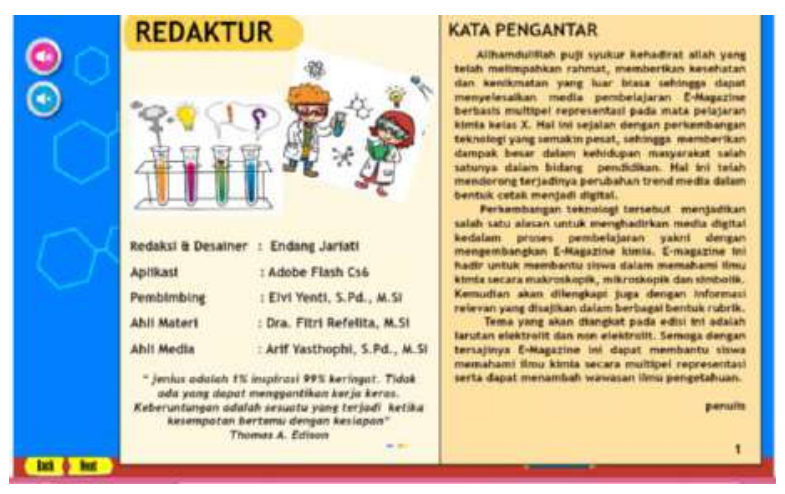

Gambar 3. Halaman redaktur dan kata pengantar

Halaman redaktur ini berisi tentang aplikasi yang digunakan serta orang-orang yang berperan dalam membantu membuat E-Magazine, sedangkan kata pengantar adalah salam pembuka dari penulis untuk menyapa pembaca.

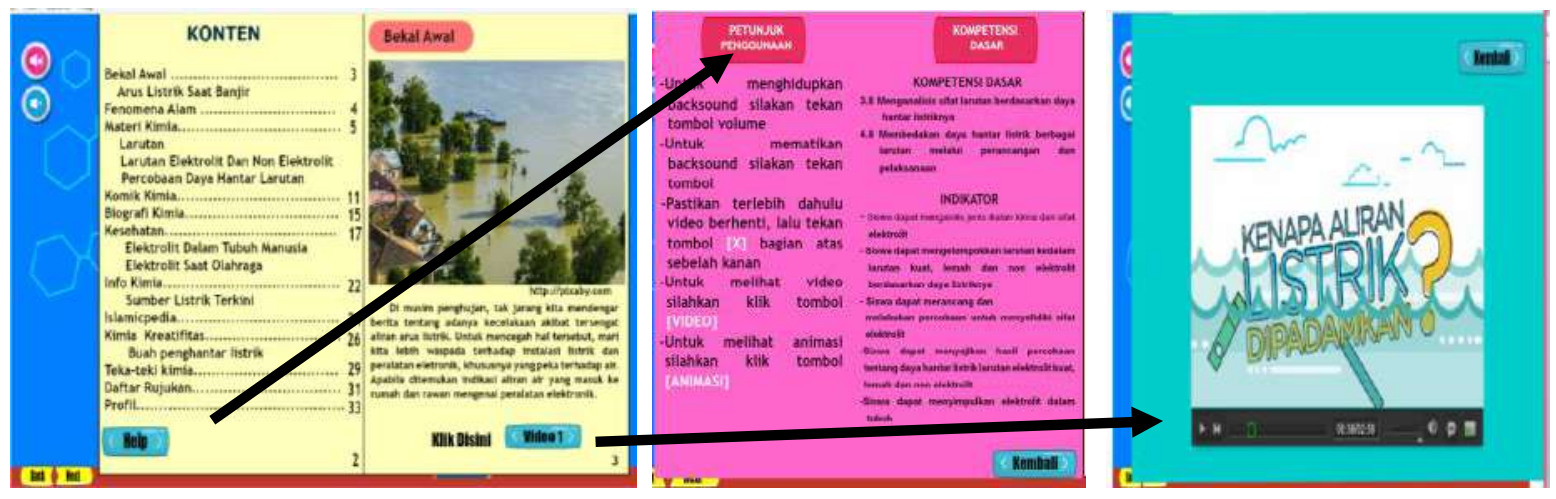

Gambar 4. Halaman konten dan bekal awal

Halaman konten ini berisi tentang konten-konten yang disajikan dalam E-Magazine. Selain hal tersebut, pada halaman konten juga terdapat tombol belp yang berisi tentang petunjuk penggunaan E-Magazine dan kompetensi dasar serta indikator pencapaian siswa. Halaman selanjutnya adalah halaman bekal awal yang berisi tentang kewaspadaan masyarakat terhadap aliran listrik saat banjir. Dalam hal ini dilengkapi dengan video agar lebih menarik dan menambah wawasan pengetahuan siswa.
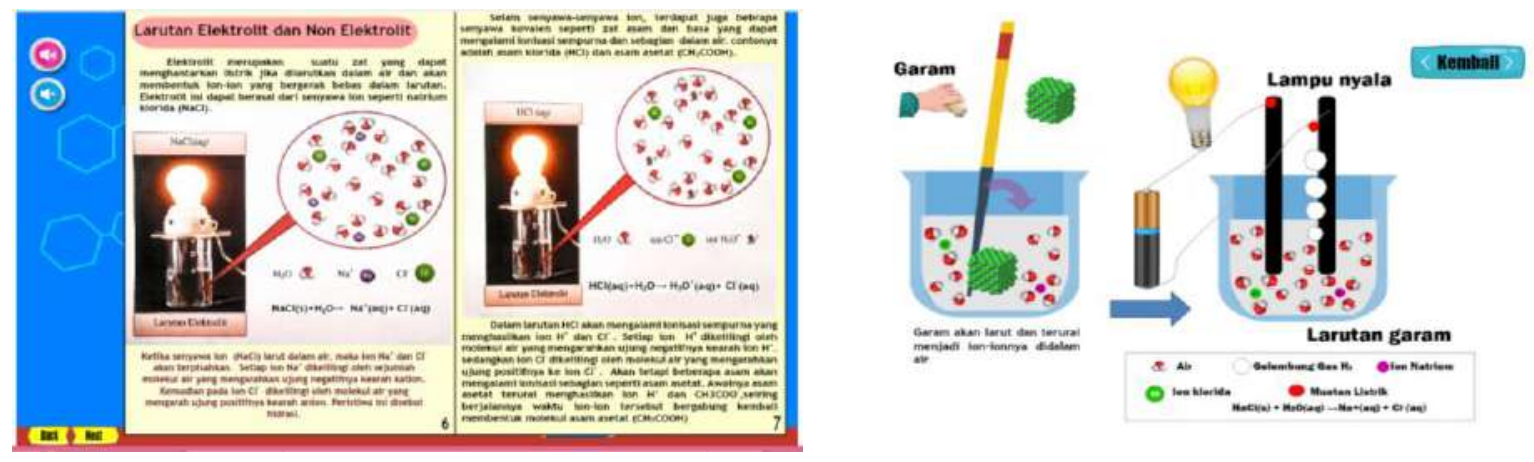

Gambar 5. Halaman materi 
Materi disajikan secara makroskopik, mikroskopik dan simbolik. Level makroskopik disajikan dengan gambar-gambar percobaan, level mikrokopik disajikan dengan bentuk molekul dari suatu larutan serta level simbolik disajikan dengan persamaan reaksi dan simbol-simbol kimia. Selanjutnya pada halaman materi ini juga disajikan rubrik percobaan larutan elektrolit dan non elektrolit.

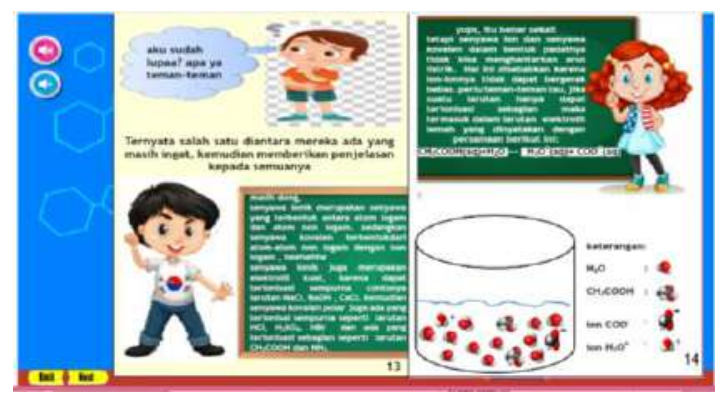

Gambar 6. Belajar kimia

Pada halaman ini terdapat percakapan singkat tentang materi larutan elektrolit dan non elektrolit.

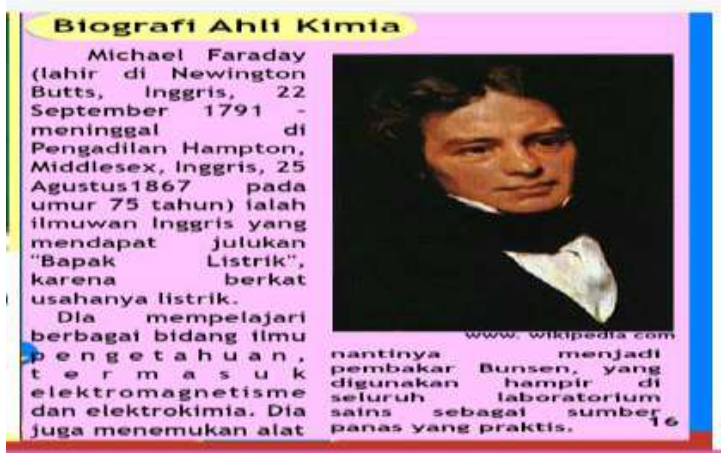

Gambar 7. Biografi ahli kimia

Halaman biografi ahli kimia ini berisi biografi Michael Faraday. Michael ini dijuluki sebagai bapak listrik karena dia adalah orang pertama yang menemukan listrik.
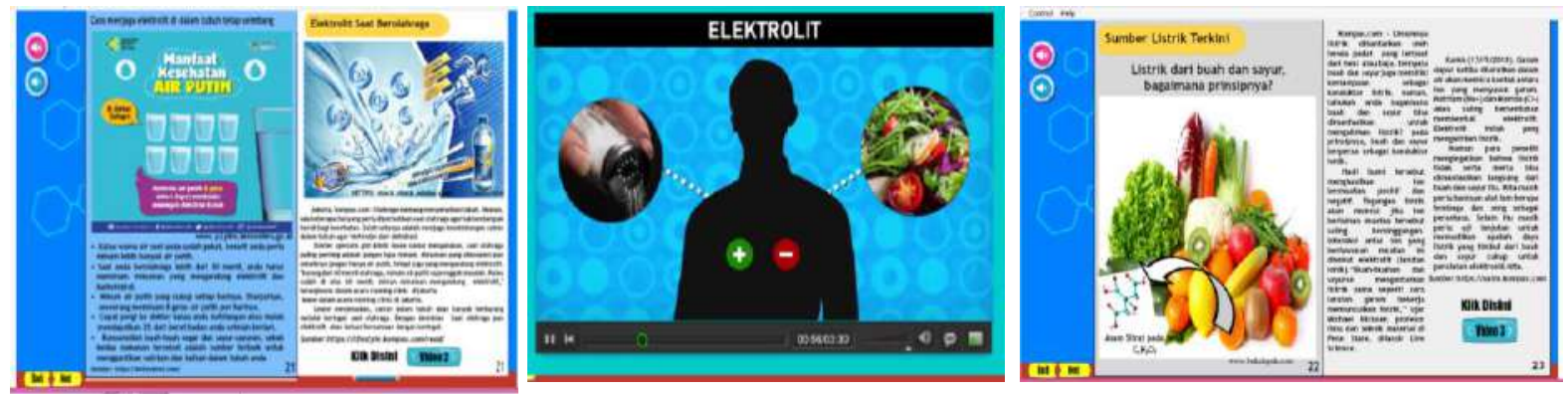

Gambar 8. Halaman info kesehatan, elektrolit dalam tubuh, buah

Pada halaman info kesehatan ini disajikan tentang pentingnya elektrolit dalam tubuh kita terutama saat olahraga yang juga dilengkapi dengan video. Kemudian terdapat sajian tentang listrik yang terdapat dalam buah salah satunya dalam buah jeruk yang dilengkapai video. Video-video yang disajikan dalam E-Magazine ini berfungsi untuk membantu siswa memahami secara mikroskopik. 


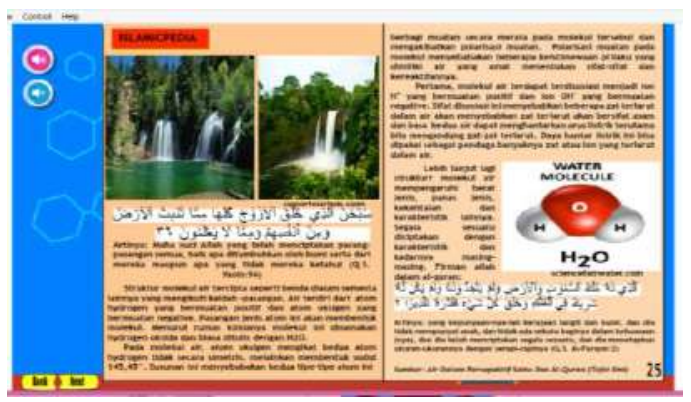

Gambar 9. Halaman islamicpedia

Islamicpedia ini berisi tentang bentuk-bentuk fisik dan kimia dari air sehingga dapat mengalirkan listrik yang terintegrasi dengan ayat Al-Qur'an.
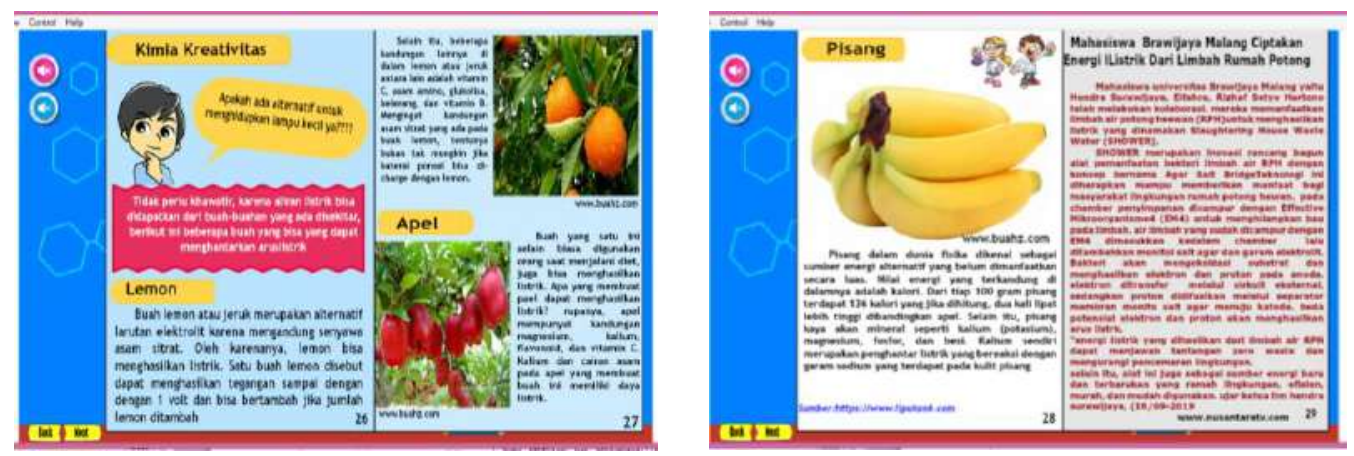

\section{Gambar 10. Kimia kreatifitas}

Halaman ini berisi informasi-informasi tentang arus listrik yang bisa didapatkan dari lingkungan sekitar seperti buah dan limbah

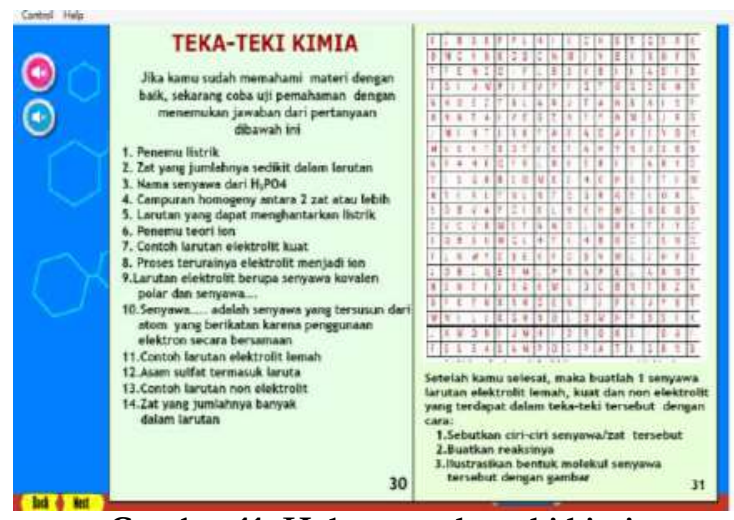

Gambar 11. Halaman teka-teki kimia disediakan.

Halaman teka-teki ini berbentuk mencari jawaban dari pertanyaan-pertanyaan yang telah

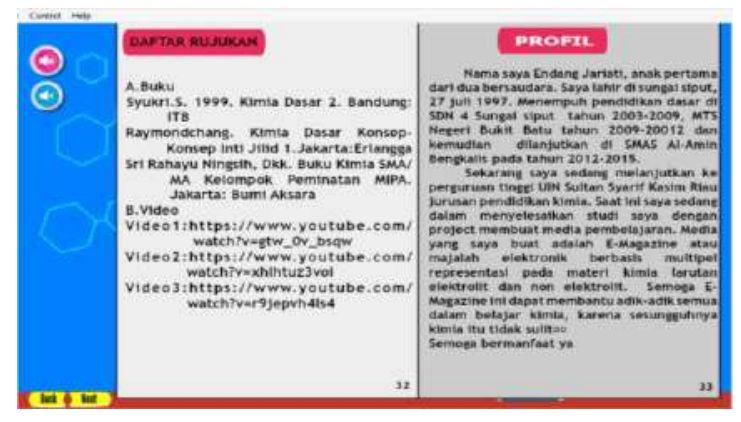

Gambar 12. Halaman sumber rujukan dan profil penulis 
Halaman sumber rujukan ini berisi tentang daftar sumber-sumber penyajian materi dari buku dan video, sedangkan untuk sumber-sumber gambar dan artikel telah disajikan dibawah setiap tulisannya. Selanjutnya yaitu halaman profil penulis yang berisi biodata singkat tentang penulis.

Penelitian yang dilakukan ini memiliki keterbatasan, yaitu dilakukan hanya tahap uji coba skala kecil dan revisi produk yang mengacu pada model penelitian Borg and Gall. Selain itu, E-Magazine yang dikembangkan hanya bisa dibuka dengan menggunakan komputer atau laptop.

\section{SIMPULAN}

Berdasarkan hasil penelitian tersebut dapat ditarik kesimpulan bahwa kualitas kevalidan E-Magazine berdasarkan penilaian validator ahli materi tergolong kategori sangat valid dengan persentase kevalidan 100\%, sedangkan kevalidan media pada E-Magazine berdasarkan validator ahli media tergolong kategori sangat valid dengan persentase kevalidan 88.46\%. Kepraktisan E-Magazine berdasarkan penilaian dari guru kimia SMA IT AL-Fityah tergolong kategori sangat praktis dengan persentase $90 \%$, sedangkan respon siswa terhadap keseluruhan isi E-Magazine adalah 50\% siswa menyatakan bagus dan 50\% lagi siswa menyatakan sangat bagus. E-Magazine yang dikembangkan pada penelitian ini hanya bisa dibuka dengan menggunakan komputer atau laptop. Untuk itu, kelanjutan dalam penelitian ini dapat dilakukan dengan cara penelitian dan pengembangan E-Magarine yang dapat diakses dan dioperasionalkan atau dibuka melalui handphone android sehingga siswa dapat lebih mudah dalam mengakses dan melakukan pembelajaran dengan menggunakan E-Magazine dalam pembelajaran. Selain itu, penelitian dapat dilanjutkan sampai tahap uji coba skala besar.

\section{REFERENSI}

Anggraeni, R. D., \& Kustijono, R. (2013). Pengembangan Media Animasi Fisika pada Materi Cahaya Dengan Aplikasi Flash Berbasis Android. Jurnal Pendidikan Fisika dan Aplikasinya, 3(1), 11-18.

Chandrasegaran, A. L., Treagust, D. F., \& Mocerino, M. (2007). The Development Of a TwoTier Multiple-Choice Diagnostic Instrument for Evaluating Secondary School Students' Ability To Describe And Explain Chemical Reactions Using Multiple Levels Of Representation. Chemistry Education Research and Practice, 8(3), 293-307.

Dwitariani, I., \& Suputra, I. D. G. D. (2016). Integritas Sebagai Pemoderasi Pengaruh Pengalaman Auditor Pada Kualitas Audit. E-Jurnal Akuntansi, 16(3), 1744-1770.

Emzir. (2017). Metodologi Penelitian Pendidikan Kauntitatif dan Kualitatif. Depok: Rajawali Press.

Fitria, F., Priatmoko, S., \& Kasmui, K. (2016). Penggunanan Multimedia Interaktif Dalam Menimalisasi Miskonsepsi Siswa Pada Materi Larutan Penyangga. Jurnal Inovasi Pendidikan Kimia, 10(1), 1641-1650.

Herda, A., Damris, M., \& Asrial, A. (2014). Pengembangan Media Interaktif pada Pembelajaran Larutan Elektrolit dan Non Elektrolit untuk Siswa SMA Kelas X. Jurnal Edu-Sains, 3(1), $22-27$.

Hsin-kai, W., Krajick, S., \& Eliot, S. (2000). Promoting Conseptual Understanding Of Chemical Representation Students' Use Of A Visualization Tool In The Classroom. 
Indrayani, P. (2012). Analisis Pemahaman Makroskopik, Mikroskopik, dan Simbolik Titrasi Asam-Basa Siswa Kelas XI IPA SMA Serta Upaya Perbaikannya Dengan Pendekatan Mikroskopik. Jurnal Pendidikan Sains, 1(2), 208-216.

Kotz, J. C., Treichel, P. M., \& Townsend, J. (2012). Chemistry And Chemical Reactivity. Cengage Learning.

Kurniawati, Y. (2019). Teknik Penyusunan Instrument Penelitian Pendidikan Kimia. Pekanbaru: Kreasi Edukasi.

Nurjanah, J. R. (2014). Pengembangan Media Interektif E-Magazine Pada Materi Pokok Dinamika Rotasi Pada Siswa SMA Kelas XI. Jurnal Materi dan Pembelajaran Fisika, 18-25.

Pakpahan, A., Gani A., \& Hasan, M. (2016). Pengembangan Majalah Kimia Pada Materi HukumHukum Dasar Kimia Kelas X. Jurnal Ilmiah Mahasiswa Pendidikan Kimia, 1(4), 52-59.

Pratiwi, N., Gardjito, G., \& Hamidah, A. (2017). Pengembangan Majalah Biologi Sebagai Media Pembelajaran Pada Pokok Bahasan Protista Kelas X MIA di SMA N 7 Kota Jambi. Biodik, 3(1), 27-34.

Putri, D.N.A., Epinur., \& Muhaimin. (2019). Pengembangan E-Magazine Materi Kesetimbangan Kimia di SMAN 1 Kota Jambi. Journal Of The Indonesian Society Of Integrated Chemistry, 11(1), 10-19.

Riduwan. (2007). Skala Pengukura Variabel-Variabel Penelitian. Bandung: Alfabeta.

Saselah, Y. R., \& Qadar, R. (2017). Interactive Multimedia Development Based on Adobe Flash CS6 Profesional on Learning of Chemical Equilibrium. Jurnal Kimia dan Pendidikan Kimia, 2(2), 80-89.

Simehatte, I., \& Nazar, M. (2016). Pengembangan Media Eleksido Menggunakan Camtasia Studio 8 Pada Larutan Elektrolit dan Non Elektrolit Untuk Siswa Kelas X MIA SMAN 1 Krueng Barona Jaya. Jurnal Imiah Mabasiswa Pendidikan Kimia, 1(3), 27-34.

Sirhan, G. (2007). Learning Difficulties in Chemistry: An Overview. Journal of Turkish Science Education, 4(2), 1-20

Sopingi. (2015). Pengantar Statistik Pendidikan Jilid 1. Malang: Gunung Samudra.

Wibanto, W. (2017). Desain dan Pemograman Multimedia Interaktif. Jember: Cerdas Ulet Kreatif.

Yani, H., Yusrizal, Y., \& Khaldun, I. (2015). Efektifitas Pendekatan Mikroskopik Dalam Lembar Kerja Peserta Didik (LKPD) Terhadap Pemahaman Konsep dan Kemampuan Berpikir Kritis Pada Materi Larutan Penyangga. Jurnal Pendidikan Sains Indonesia2, 3(1), 38-46.

Yuliyanto, E., \& Rohaeti, E. (2013). Pengembangan Majalah Kimia untuk Meningkatkan Motivasi Belajar dan Kreativitas Peserta Didik Kelas X SMAN 1 Milati. Jurnal Pendidikan Sains, 1(1), $1-15$. 